\title{
The Influence of Accounting Comparability on the Audit Fees
}

\author{
Jin-Jian Yang* \\ School of Accounting, Wuhan \\ Textile University, Wuhan Hubei, \\ China \\ Email: yjj@wtu.edu.cn \\ *Corresponding author
}

\author{
Zi-Xuan Zhou \\ School of Accounting, Wuhan \\ Textile University, Wuhan Hubei, \\ China
}

\author{
Yi-Wen Wang \\ School of Computer and \\ Communication Engineering, \\ Northeastern University, \\ Qinhuangdao Hebei, China
}

\begin{abstract}
Based on the Simunic model and the surplusearnings regression model (De Franco et al.), we build a research model according to the relationships between variables of the audit input, risk premium and accounting comparability. The result shows that the accounting comparability has a huge effect on audit fees. Companies having a high level of accounting comparability collect low audit fees, vice versa. Further research shows that, the accounting comparability influences the audit fees through two ways. One is to improve the efficiency of obtaining external information and enhance the auditability on the financial statement, and then decrease the input on the audit by reducing the human capital investment. The other is to reduce the audit risk so as to decrease the risk premium required by accountant. The research also shows that the first influence way is more remarkable comparing to the second way.
\end{abstract}

Keywords-Accounting Comparability; Audit Fees; Audit Risk; Auditability

\section{INTRODUCTION}

Audit fee, also named as audit pricing, refers to the fee charged by accountants when they provide audit service to their clients. Reasonable audit fee is the basic premise to promote audit firm development and provide high quality audit report, which is of great significance for protecting the public interest and improving the efficiency of collocation of capital market resources.

Accounting comparability is an important part of the quality characteristics of the accounting information. Comparability requires companies which have identical or similar economic business to provide similar accounting information, while requiring those companies developing different business to provide apparently different accounting information. When accounting comparability becomes stronger, the user can better understand the company's true financial situation and business performance.

According to new audit risk model, audit risk depends on risk of material misstatement and detection risk. Among them, detection risk is related to the ability and independence of auditors. Taken no self-characteristics of auditors into consideration, audit risk mainly depends on risk of material misstatement. Due to certified public accountants decide audit input and audit risk compensation on the basis of different risk of material misstatement, accounting comparability will influence the audit fee.
However, since Simunic (1980) opens the door to the empirical research of audit fee, many researchers at home and abroad have not put accounting comparability into empirical research when researching audit fee. The main reason is the great difficulty accounting comparability measurement. This article, based on empirical research, will put accounting comparability into audit fee model to investigate the influence of accounting comparability in our listed companies on audit fee.

\section{MAIN VARIABLES AND HYPOTHESES}

\section{A. The Determinants of Audit Fees}

\section{1) Audit Input}

Audit input primarily refers to the fees on performing specific audit engagements, such as evidence collecting cost, communication cost and coordination cost with relevant personnel in clients. There is close relationship between audit input and audit risk. The business risk and financial risk of clients will dramatically affect the quantity and quality of audit input, finally affect audit fees.

\section{2) Risk Premium}

Audit input and risk premium have a reciprocal relationship. The higher audit input is, the lower audit risk will be, which indicates when taking more audit procedures, expected loss will reduce in the future, vice versa. Therefore, when auditor perform audit procedures, according to acceptable risk level, they should determine appropriate audit input and make the sum of audit input and risk premium the least to improve audit efficiency.

\section{B. Accounting Comparability and Audit Fees}

\section{1) Accounting Comparability and Audit Input}

The influence of accounting comparability on audit fees reflects on two aspects. The one is improving the efficiency of auditor to obtain audit evidence, the more the accounting comparability in clients is, the higher the efficiency of auditor to obtain audit evidence is. The other one is benefiting auditors make effective assessment to client's risk, the higher the accounting comparability is, the lower the risk of material misstatement will be. Therefore, the higher the client's accounting comparability is, the lower the audit input from audit firm will be. 


\section{Accounting Comparability and Audit Premium}

The higher accounting comparability in client is, the lower the risk premium accountant fee is. Contrarily, the risk premium accountant fee will be higher.

\section{The Research Hypotheses}

Based on theoretical analysis above, we first examine the influence of accounting comparability on audit fees, leading to our first hypothesis:

H1: accounting comparability and audit fees is negatively related. When other condition remains unchanged, the higher accounting comparability is, the lower audit fees will be.

Then we further examine the influence way to reduce audit fees by accounting comparability. According to theoretical analysis above, there are two influence ways. One is improving efficiency of gaining external information and audit auditability in order to reduce the audit input further by reducing accountant's human resource input, the other is reducing risk premium required by accountants through reducing audit risk. Thus, we propose the second hypothesis.

H2a: accounting comparability benefits reducing the sensitivity of the complexity between audit fees and client business performance, meaning when other condition remains unchanged, with the reinforce of accounting comparability, the positive correlation of the complexity between audit charges and client business performance will decrease.

H2b: accounting comparability benefits reducing the sensitivity of audit fees and audit risk, meaning when other condition remains unchanged, with the reinforce of accounting comparability, the positive correlation of audit fees and audit risk will reduce.

\section{RESEARCH DESIGN}

\section{A . The Measurement of Accounting Comparability}

De Franco et al. (2011) define company accounting system as the transformation process when business transactions produce financial statement. If two companies have similar accounting system, the same business transactions should transform into similar accounting information. De Franco et al. (2011) take stock yield to represent the influence of business transactions on the company, using accounting earnings to represent company's accounting information. In order to calculate the t period in accounting system of company $i$, we use sixteen consecutive quarters data before the $\mathrm{t}$ period, using accounting earnings as explained variables, using quarterly stock yield ( Returnit)as explanatory variables to perform regression. However, since the company's uncertainty on the recognition of good news and bad news, the company accounting system confirms bad news timelier than good news, whose result may be biased. Namely the good news and bad news mean earnings and loss or negative and positive stock earnings. We introduce the stock earnings dummy variable (Negit) and the cross term of stock yield and stock earnings dummy variable (Negit*Returnit) to evaluate company accounting system, the special regression model is as follows.

$$
\text { Earning }_{i t}=\alpha_{i}+\beta_{i} \text { Return }_{i t}+c_{i} \operatorname{Neg}_{i t}+d_{i} N g_{i t} * \operatorname{Return}_{i t}+\varepsilon_{i t}
$$

In the equation (1), if Negit represents the Returnit negative, it equals to 1 , otherwise it equals to 0 . In order to further estimate how close the two company accounting systems are, we assume that economic business of the two company are same, and they are both Returnit. Then, use the transfer function of the two companies respectively to calculate their expected earnings.

$$
\begin{gathered}
\text { E(Earnings })_{i i t}={ }_{i}+{ }_{i} \text { Return }_{i t}+{ }_{i} \text { Neg }_{i t}+{ }_{i} N e g_{i t} * \text { Return }_{i t} \\
\text { (2) }
\end{gathered}
$$

Equation (2) and (3) represent the expected earnings of company $\mathrm{i}$ and $\mathrm{j}$ in given economic business respectively, defining accounting comparability of company $i$ and $j$ as the opposite number of absolute average expected surplus differences in these two companies:

$$
\text { Comp }_{i j t}=-\frac{1}{16} \times \sum_{t-15}^{t} \mid E(\text { Earnings })_{i i t}-E(\text { Earnings })_{i j t} \mid
$$

According to the methods above, we match company $\mathrm{i}$ with other companies within the industry, calculating accounting comparability of each match. The higher value means accounting comparability is stronger, and vice versa. Considering investors only choose four to six companies in industry instead of all companies, when assessing invest chances, we rank the index value of comparability of accounting information calculated by matching company $i$ with other companies within the industry in descending order, and then choose the average value of the first four as the measurement of accounting comparability (CompAccit) in company $\mathrm{i}$.

\section{B . Test Model and Variable Definition}

In order to examine hypothesis 1 , we built a model as follows:

$$
\begin{aligned}
& \log \mathrm{Fee}_{\mathrm{it}}=\alpha+\beta_{1} * \mathrm{CompAcc}_{\mathrm{it}}+\beta_{2} * \log \operatorname{Size}_{\mathrm{it}}+\beta_{3} * \mathrm{Rec}_{\mathrm{it}}+ \\
& \beta_{4} * \operatorname{Lev}_{\text {it }}+\beta_{5}{ }^{*} \text { sqsjyj }_{\text {it }}+\beta_{6} * \operatorname{loss}_{\text {it }}+\beta_{7} * \mathrm{Big}_{\mathrm{it}}+\mathrm{indFE}_{+} \\
& \text {yearFE }+\varepsilon_{i t}
\end{aligned}
$$

In equation (5), i represents company, $\mathrm{t}$ represents year. $\log F$ ee means the natural logarithm of annual financial report audit fees, CompAccit represents accounting comparability. logSize indicates the size of company, equaling to the natural logarithm of total company assets. 
Rec is the ratio of receivables to total company asset, the two variables represent the complexity of company business. Lev refers to the company gearing, equaling to the ratio of total liability to total assets. Sqsjyj is the dummy variable of previous unqualified opinions issued by auditors, if the previous unqualified opinions issued by the auditor equals to 1 , otherwise it equals to 0 . Loss means the loss of dummy variable during the recent three years, if there is at least one year loss equaling to 1 during the last three years, and otherwise it equals to 0 . We use these three varies to represent the company's audit risk and business risk. Big 4 indicate whether the audit firm is the international big four firms, if the firm is, the value equals to 1 , otherwise is 0 . indFE and yearFE represent industry effect and annual effect respectively. If the assumption is true, the regression coefficient $\beta 1$ in model (5) will be negative.

In order to examine hypothesis 2 , we also introduce the cross term of accounting comparability and company business complexity variables into our model-the cross term of accounting comparability and audit risk and business risk. The formula is as follows.

$$
\begin{aligned}
& \log \mathrm{Fee}_{\mathrm{it}}=\alpha+\beta_{1} * \mathrm{CompAcc}_{\mathrm{it}}+\beta_{2} * \log \mathrm{Size}_{\mathrm{it}}+\beta_{3} * \mathrm{Rec}_{\mathrm{it}}+ \\
& \beta_{4} * \operatorname{Lev}_{\mathrm{it}}+\beta_{5}{ }^{*} \mathrm{sqsjyj}_{\mathrm{it}}+\beta_{6} * \operatorname{loss}_{\mathrm{it}}+\beta_{7} * \mathrm{Big} 4_{\mathrm{it}}+ \\
& \beta_{8} * \operatorname{CompAcc}_{\mathrm{it}} * \log \operatorname{Size}_{\mathrm{it}}+\beta_{9} * \operatorname{CompAcc}_{\mathrm{it}} * \mathrm{Rec}_{\mathrm{it}}+ \\
& \beta_{10} * \operatorname{CompAcc}_{\mathrm{it}} * \operatorname{Lev}_{\mathrm{it}}+\beta_{11} * \operatorname{CompAcc}_{\mathrm{it}} * \mathrm{sqsjyj}_{\mathrm{it}}+ \\
& \beta_{12} * \operatorname{CompAcc}_{\mathrm{it}} * \operatorname{loss}_{\mathrm{it}}+\beta_{13} * \operatorname{CompAcc}_{\mathrm{it}} * \mathrm{Big}_{\mathrm{it}}+\text { indFE }+^{-} \\
& \text {yearFE }+\varepsilon_{\text {it }}
\end{aligned}
$$

\begin{tabular}{|c|c|c|}
\hline explained variable & $\operatorname{logFee}$ & Audit fees, equals to the logarithm of annual audit fees(ten thousand unit) \\
\hline $\begin{array}{l}\text { explanatory variable: accounting } \\
\text { comparability }\end{array}$ & CompAcc & Calculate based on revised De Franco et al. (2011)model \\
\hline \multirow{2}{*}{$\begin{array}{l}\text { explanatory variable: business } \\
\text { complexity }\end{array}$} & $\operatorname{logSize}$ & the logarithm of total assets, unit: ten thousand \\
\hline & $\operatorname{Rec}$ & The proportion of receivables in total assets \\
\hline \multirow{3}{*}{$\begin{array}{l}\text { explanatory variable: audit risk and } \\
\text { business risk }\end{array}$} & Lev & Assets/liability ratio: total liabilities/ total assets \\
\hline & sqsjyj & Equal to 1 if given unqualified audit opinion by auditor in previous period, and otherwise 0 . \\
\hline & loss & Equal to 1 if there is at least one year loss during recent three years, and otherwise 0 . \\
\hline \multirow{3}{*}{ other control variables } & Big4 & Equal to 1 if it is international big four firm, and otherwise 0. \\
\hline & IndFE & industry effect \\
\hline & yearFE & annual effect \\
\hline
\end{tabular}

If the hypothesis 2 is true, regression coefficient $\beta_{8}-\beta_{13}$ will be negative. The definition and description of model (5) and (6) is listed in Table 1.

TABLE I. THE DEFINITION AND DESCRIPTION

\section{C . The Source of Data and Sample Selection}

The data needed by the research all from Ifind finance terminal. China began mandatory disclosure of quarterly reports from 2002, and disclosed the payment to accounting firm in annual report as important events. Since the previous 16 quarters relevant data should be used when calculating accounting comparability, the earliest one that accounting comparability can be calculated is in 2005, therefore the sample interval of this research is from 2005 to 2014. The selection of research sample and relevant index calculation is following the principles below. Based on the companies which have complete sixteen quarters stock exchange information and quarter data since the year ended, eligible companies are eliminated as follows. The first one is the company in financial industry. The second one is the company which doesn't have five-year data. Thirdly, the industry has no more than eight companies. Fourthly, those companies can't gain complete relevant data. Finally, we gain 12108 companies' annual report data. 


\section{RESEARCH RESULTS}

\section{A . Descriptive Statistics}

The descriptive results of variables are showed above in TABLE II . The average of audit fees in logs (unit: million) is 1.81 , meaning that the average auditor fees is about $65\left(10^{1.81}\right) \mathrm{m}$. The average value of accounting comparability is $0.3 \%$, indicating if the business transactions are the same, the quarter accounting profit of a middle-scale listed company with one billion market value would be more than $30 \mathrm{~m}$. Then the difference will further be about 0.12 billion in a year. This also indicates that accounting comparability in our listed companies is not high enough. For those listed companies, $5.8 \%$ of them are audited by big firms, $5.2 \%$ of them are issued modified audit opinion last year and 23.6 companies have at least one loss during the last three years.

TABLE II. THE DESCRIPTIVE RESULTS OF VARIABLES

\begin{tabular}{|c|c|c|c|c|c|c|}
\hline variables & $\mathrm{n}$ & mean & median & Std.deviation & The 1st quantile & The 99th quantile \\
\hline $\operatorname{logFee}$ & 12108 & 1.81 & 1.78 & 0.292 & 1.301 & 2.789 \\
\hline CompAcc & 12108 & -0.003 & 0 & 0.003 & -0.016 & 0 \\
\hline logSize & 12108 & 5.49 & 5.44 & 0.548 & 4.329 & 0.014 \\
\hline Rec & 12108 & 0.009 & 0.01 & 0.01 & 0.062 & 1.153 \\
\hline Lev & 12108 & 0.521 & 0.51 & 0.611 & 0 & 1 \\
\hline sqsjyj & 12108 & 0.052 & 0 & 0.222 & 0 & 1 \\
\hline Big4 & 12108 & 0.058 & 0 & 0.233 & 0 & 1 \\
\hline loss & 12108 & 0.236 & 0 & 0.425 & & 0.042 \\
\hline
\end{tabular}

B. Relevant Analysis

The results of Pearson's relevant analysis are showed in TABLE III.

TABLE III. VARIABLES IN PEARSON'S RELEVANT ANALYSIS

\begin{tabular}{|c|c|c|c|c|c|c|c|c|}
\hline variables & $\operatorname{logFee}$ & CompAcc & $\log$ Size & $\operatorname{Rec}$ & Lev & sqsjyj & Big4 & loss \\
\hline $\log \mathrm{Fee}$ & $1.000(0.000)$ & & & & & & & \\
\hline $\begin{array}{c}\text { CompAc } \\
\mathrm{c}\end{array}$ & $-0.062(0.000)$ & $1.000(0.000)$ & & & & & & \\
\hline $\log$ Size & $0.719(0.000)$ & $-0.008(0.000)$ & $1.000(0.000)$ & & & & & \\
\hline $\operatorname{Rec}$ & $-0.075(0.000)$ & $0.161(0.000)$ & $-0.168(0.000)$ & $1.000(0.000)$ & & & & \\
\hline Lev & $0.043(0.000)$ & $-0.223(0.000)$ & $0.003(0.703)$ & $-0.019(0.033)$ & $1.000(0.000)$ & & & \\
\hline sqsjyj & $-0.081(0.000)$ & $-0.320(0.000)$ & $-0.207(0.000)$ & $-0.001(0.909)$ & $0.211(0.000)$ & $1.000(0.000)$ & & \\
\hline Big4 & $0.477(0.000)$ & $-0.056(0.000)$ & $0.333(0.000)$ & $-0.059(0.000)$ & $0.004(0.699)$ & $-0.034(0.000)$ & $1.000(0.000)$ & \\
\hline loss & $-0.118(0.000)$ & $-0.428(0.000)$ & $-0.242(0.000)$ & $-0.026(0.004)$ & $0.141(0.000)$ & $0.306(0.000)$ & $0.059(0.000)$ & $1.000(0.0)$ \\
\hline
\end{tabular}

Note: the value in ( ) is the value P, indicating the significance level

As showed in TABLE III, accounting comparability and audit fees are negatively related, which further examines the hypothesis1. The relationship of audit fees and other variables is as follows. The audit fees and the scale are positively related, showing that the more complicated the business in auditees is, the higher the audit fees will be. The audit fees and asset-liability ratio are positively related, meaning when the financial risk in auditees is higher, the more audit fees will be charged. Also audit fee is positively related with whether the auditor belongs to the big four, the 
big four charge higher fees. All of these are consistent with the results in existing literatures. But accounting comparability shows an opposite expectation with the correlation coefficients in variables of receivables, previous period of modified audit opinions, at least one year loss during recent three years. Therefore, other variables would be controlled to conduct further regression analysis. The relevant analysis showed in TABLE III also indicates that the absolute value of the correlation coefficients in each explanatory variables are all less than 0.5 , showing variables have no significant collinearity.

\section{Multiple Regressions}

In order to examine the hypothesis1, we make regression analysis by using audit fees and accounting comparability as explanatory variable to control some indexes reflecting the complexity of audit unit, audit risk and business risk, like the scale of audit unit, the proportion of receivable in assets, assets/ liabilities ratio and so on. The result is showed in the M1line in TABLE IV.

TABLE IV. THE INFLUENCE OF ACCOUNTING COMPARABILITY ON AUDIT FEES

\begin{tabular}{|l|l|l|}
\hline Varibles & M1 & M2 \\
\hline CompAcc & $-4.763^{* * *(-7.054)}$ & \\
\hline rank_CompAcc & & $-0.030^{* * *(-4.334)}$ \\
\hline logSize & $0.343^{* * *(93.495)}$ & $0.343 * *(91.866)^{*}$ \\
\hline Rec & $1.285^{* * *(6.349)}$ & $1.301 * * *(6.401)$ \\
\hline Lev & $0.014 * * *(4.919)$ & $0.016^{* * *(5.568)}$ \\
\hline sqsjyj & $0.053^{* * *(6.316)}$ & $0.061 * * *(7.455)$ \\
\hline loss & $0.016^{* * *(3.486)}$ & $0.020 * * *(4.099)$ \\
\hline Big4 & $0.344^{* * *(45.025)}$ & $0.344 * * *(45.005)$ \\
\hline indFE & controllable & controllable \\
\hline yearFE & controllable & controllable \\
\hline $\mathrm{R}^{2}$ & 0.611 & 0.610 \\
\hline Adapted $\mathrm{R}^{2}$ & 0.610 & 0.609 \\
\hline Observation number & 12108 & 12108 \\
\hline
\end{tabular}

Note: The value in ( ) is the value $\mathrm{T}$ and $*, * *, * * *$ indicates the $10 \%, 5 \%, 1 \%$ significance level respectively.

The M1line in TABLE IV shows that regression coefficient of accounting comparability is -4.763 , under the significance level of $1 \%$. When other factors remain unchanged, a standard deviation of 0.003 causes a decline in audit fees about $3.34 \%\left(10^{4.763 * 0.003}-1\right)$. Further, accounting comparability can be ranked from small to large into10 groups dividing by year and numbered from 0 to 9 . Then each group divides 9 and gains a ranking index of accounting comparability (rank_CompAcc), which has the lowest value 0 and the highest value 1 . Replace this index with CompAcc as explanatory variable and repeat the above regression analysis, the result is showed in the M2 line in TABLE IV. Regression coefficient of rank_CompAcc is 0.030 , prominent under the significance level of $1 \%$. The coefficient -0.030 means that the difference in logs between the highest value group and the lowest value group equals to 0.03 . That indicates when other factors remain unchanged, audit fees in lowest value group is $7.15 \%\left(10^{0.03}-1\right)$ more than the highest one. When other factors are not controlled, the difference in audit fee between the lowest value group and the highest one is about $19 \mathrm{~m}(69 \mathrm{~m}-50 \mathrm{~m})$, the relative proportion of which is $38 \%$ (the result isn't reported). The result in other controllable variables is consistent with existing literatures.

\section{V.CONCLUSION AND SUGGESTION}

The contribution of this study is to make up for the deficiency of existing literature which haven't introduced accounting comparability into audit fees model and to expand the research in the economic consequence of accounting comparability into the auditor fees area. The policy implication of the research result on company's accounting comparability can reduce the audit cost, further reducing the audit fees. The purpose of the research is to further improve accounting comparability, for related 
government department regulate the healthy development in the accounting industry and improve the audit efficiency.

\section{REFERENCES}

[1] Simunic D A. The pricing of audit services: Theory and evidence. Journal of accounting research. (1980) 61-190.

[2] Houston R W, Peters M F, Pratt J H. Nonlitigation risk and pricing audit services. Auditing: A Journal of Practice \& Theory, 24(2005) $37-53$.
[3] Wang Shanping, Li Bin, Positive Analysis on Factors Influencing Audit Fee of the Listed Companies of China. The theory and practice of finance and economics, 2(2004) 68-71.

[4] Zhu Xiaoping, Yu Qian, The Determinants of Audit Fees: An Empirical Analysis in China. CHINA ACCOUNTING REVIEW, 2(2004) 393-408.

[5] Chen Xiaolin, Potential Misstatement Risk, Information Transparency and Audit Pricing---Evidence from Chinese Securities Market, Scientific Decision Making,8(2009) 10-16.

[6] Xu Chaoyang, Liu Ruizhi, Can Accounting Comparability Reduce Earnings Management? Accounting Research, 7 (2014) 007. 